\title{
Editorial RES 2/2019
}

One of the first issues of our journal was dedicated to the topic of "JewishChristian dialogue in the Orthodox space". The decision of the earlier editorial team was no coincidence. It is an expression of the conviction that the Jewish-Christian dialogue is not simply about cultivating one of the many interreligious relationships. Rather, it gives voice to the reflection on the first major break that shaped early Christianity, namely, that between the Jews who believed in Jesus as the Messiah and those who rejected Him.

We are delighted that after ten years RES can again publish research on the Judeo-Christian dialogue from a Christian Orthodox perspective. More specifically, this issue is the first fruit of a broader three-year research project at the Institute of Ecumenical Research, which is entitled "Jewish-Christian Dialogue in the Twentieth Century between Religious Tolerance and Anti-Semitism: Documents, Interpretations and Perspectives in the Christian Orthodox Context". 1 However, the contributions have a very specific thrust in this volume: the authors are concerned with the

This project has been made possible through a research grant from the Romanian government agency UEFISCDI in the 2016 competition, as PN-III-P4-ID-PCE- 20160699, http://ddic.ecum.ro/en/.
Eine der ersten Nummern unserer Zeitschrift war dem Thema des ,jüdisch-christlichen Dialogs im orthodoxen Raum" gewidmet. Die Entscheidung des damaligen Teams war kein Zufall. Sie ist Ausdruck der Überzeugung, dass es beim jüdisch-christlichen Dialog nicht einfach um die Pflege einer der vielen interreligiösen Beziehungen geht. Vielmehr widerspiegelt sich darin das Nachdenken über den ersten großen Bruch, der die frühe Christenheit geprägt hat, nämlich denjenigen zwischen den Juden, die an Jesus als den Messias glaubten, und denjenigen, die ihn ablehnten.

Wir freuen uns, dass RES zehn Jahre später wieder Untersuchungen zum jüdisch-christlichen Dialog aus orthodoxer Sicht publizieren kann. Genauer gesagt ist diese Ausgabe erste Frucht eines breiteren dreijährigen Forschungsprojektes des Instituts, das den Titel trägt „Jewish-Christian Dialogue in the Twentieth Century between Religious Tolerance and Anti-Semitism: Documents, Interpretations and Perspectives in the Christian Orthodox Context". ${ }^{1}$ Die Beiträge haben diesmal allerdings eine ganz bestimmte Richtung: es geht den Autoren um die Frage nach

Durchgeführt unter dem Dach der Universität Lucian Blaga, finanziert von der rumänischen Regierungsagentur UEFISCDI unter dem Kürzel PN-III-P4-ID-PCE2016-0699), http://ddic.ecum.ro/en/. 
question of the problem of antiJudaism in liturgical and patristic texts. More than 70 years after the Shoah and more than 50 years after the crucial shift in the relation to Judaism, which the Catholic Church has marked through the Second Vatican Council document Nostra Aetate, it becomes clear to many Orthodox theologians that the difficulty in the dialogue between Judaism and the Orthodox Church lies precisely in the deep attachment the latter unwaveringly preserve to their liturgical and patristic tradition.

We are especially pleased to be able to offer this issue of RES to all participants in the conference "The Byzantine Liturgy and the Jews" (911 July 2019) ${ }^{2}$. The fact that such a conference has been made possible shows that the bone of contention in the Jewish-Christian dialogue, namely the anti-Jewish texts of the Christian tradition, can be maturely addressed and reconsidered.

This new approach is particularly outlined by Sandrine Caneri, who asks in what circumstances the Orthodox Christians would engage in the Judeo-Christian dialogue. This question puts the reader in a somewhat uncomfortable but undoubtedly fertile position. The author emphasizes the need to study oral Jewish and Christian traditions in parallel. The task is tremendous, but it promises corresponding re-

\footnotetext{
2 http://ddic.ecum.ro/category/evenimente/.
}

dem Problem des Antijudaismus in liturgischen und patristischen Texten. Über 70 Jahre nach der Shoa und mehr als 50 Jahre nach der entscheidenden Neuausrichtung im Hinblick auf die Beziehung mit dem Judentum, die die katholische Kirche im Konzilsdokument Nostra Aetate vorgenommen hat, wird es für viele orthodoxe Theologen deutlich, dass die Schwierigkeit im Dialog zwischen Judentum und Orthodoxer Kirche genau darin liegt, dass letztere unverrückbar an ihrer liturgischen und patristischen Tradition festhält.

Besonders freuen wir uns, dass wir diese Nummer von RES allen Teilnehmern der Konferenz „Byzantine Liturgy and the Jews" (9. - 11. Juli 2019) ${ }^{2}$ anbieten können. Die Tatsache, dass eine solche Konferenz zustande kam, zeigt, dass der Zankapfel im jüdisch-christlichen Dialog, nämlich die antijüdischen Texte der christlichen Tradition, zur Diskussion gestellt und neu bedacht werden können.

Diese neue Herangehensweise wird im Speziellen von Sandrine Canteri umrissen, indem sie sich fragt, unter welchen Bedingungen orthodoxe Christen sich im jüdisch-christlichen Dialog engagieren würden. Diese Frage bringt den Leser in eine etwas unbequeme, aber zweifellos fruchtbare Lage. Die Autorin unterstreicht die Notwendigkeit, die mündlichen jüdischen und christlichen Traditionen parallel zu untersuchen. Diese Aufgabe ist immens, aber sie verspricht entspre-

2 http://ddic.ecum.ro/category/evenimente/. 
sults, and it has been approached only to a modest extent. A small but important step in this direction is made by Ioan Moga, who points to the importance of the Jewish elements found in the rich liturgical and theological traditions of the Orthodox Church.

The critical point of patristic anti-Judaism is addressed in the contribution of Seraphim Seppälä. From the position of an Orthodox theologian, he dares to argue that the attitude of some patristic authors towards Judaism is unlikely to fit the attitude we should be guided by in the 21 st century. In the decades since the beginning of the dialogue with Judaism, the necessary theological discernment has been developed, and therein is a great gain; At the same time, however, it is an issue that is extremely sensitive for Orthodox Christians because of their close ties to the Church Fathers.

Alexandru Prelipcean offers a detailed documentation of the discussion, which has been going on for almost a century, on the question of the possible Jewish origin of one of the most famous and popular hymnographers of the Byzantine tradition, namely Romanos Melodos. This article addresses the highly controversial theme of Jewish elements in the Byzantine Orthodox liturgy.

Demetrios Tonias introduces the complex question of continuity chende Resultate, und sie ist erst ansatzweise angegangen worden. Einen kleinen, aber wichtigen Schritt in dieser Richtung geht Ioan Moga, der auf die Bedeutung der jüdischen Elemente hinweist, die in der reichen liturgischen und theologischen Tradition der Orthodoxen Kirche zu finden sind. Den neuralgischen Punkt des patristischen Antijudaismus spricht der Beitrag von Seraphim Seppälä an. Als orthodoxer Theologe wagt er es zu behaupten, dass die Einstellung einiger patristischer Autoren gegenüber dem Judentum wohl kaum der Haltung entspricht, von der wir uns im 21. Jahrhundert leiten lassen sollten. In den Jahrzehnten seit dem Beginn des Dialogs mit dem Judentum wurde das dafür erforderliche theologische Unterscheidungsvermögen entwickelt, und darin liegt ein großer Gewinn; zugleich ist es aber ein Thema, das für orthodoxe Christen wegen ihrer engen Bindung an die Kirchenväter überaus heikel ist.

Alexandru Prelipcean bietet eine detailreiche Dokumentation der Diskussion, die schon fast ein Jahrhundert andauert, zur Frage nach der eventuellen jüdischen Herkunft des bekanntesten und beliebtesten Hymnografen der byzantinischen Tradition, nämlich Romanos Melodos. Mit diesem Beitrag wird das äußerst umstrittene Thema der jüdischen Elemente in der byzantinischen orthodoxen Liturgie angesprochen. Demetrios Tonias gibt eine Einführung in die komplexe Frage nach Kontinuität und Erfüllung in der Beziehung zwischen Judentum und 
and fulfilment in the relationship between Judaism and Christianity and points out that one can by no means label a whole theological tradition with the simple etiquette of "supersessionist theology." The close interweaving of biblical and patristic texts in the Eastern Church liturgy and theology makes such an analysis correspondingly difficult. Rash judgments are prone to errors and should give way to patience, similar to what the restorer of an antique garment must muster. This is also the direction of Alexandru Mihăilăs contribution, which points to the close affinity between the biblicalprophetic language and the Byzantine liturgy.

The difficulties of the modern approach to a two-thousand-year history are particularly evident when an Orthodox Christian wants to engage in dialogue with Judaism, as both Judaism and Christianity have been developed also as delineation from each other. Just how difficult this undertaking can be is shown by Alexandru Ioniţă in his contribution on Byzantine hymnography as a stumbling stone in the last decades of dialogue. His suggestion, however, goes beyond establishing a mutual lack of understanding, pointing rather to the diversity of Jewish elements in the Byzantine hymnography and liturgy.

Finally, Sister Éliane Poirot offers a concise overview of the whole JudeoChristian dialogue in modern times
Christentum und zeigt auf, dass man keinesfalls eine ganze theologische Tradition mit der einfachen Etikette "Substitutionstheologie” versehen kann. Die engen Verflechtungen von biblischen und patristischen Texten in der ostkirchlichen Liturgie und Theologie machen eine solche Analyse entsprechend aufwendig. Vorschnelle Urteile sind anfällig für Fehler und sollten der Geduld Platz machen, ähnlich derjenigen, die der Restaurator eines antiken Kleidungsstücks aufbringen muss. In diese Richtung geht auch der Beitrag von Alexandru Mihăilă, der auf die enge Verwandtschaft zwischen der biblisch-prophetischen Sprache und der byzantinischen Liturgie hinweist.

Die Schwierigkeiten des modernen Umgangs mit einer zweitausendjährigen Geschichte zeigen sich besonders dann, wenn ein orthodoxer Christ in den Dialog mit dem Judentum eintreten will, weil beide, Judentum und Christentum, sich in Abgrenzung zueinander entwickelt haben. Wie schwierig diese Unternehmung sein kann, zeigt Alexandru Ioniță in seinem Beitrag zur byzantinischen Hymnographie als Stolperstein der letzten Jahrzehnte des Dialogs. Sein Vorschlag geht aber über die Feststellung eines gegenseitigen Unverständnisses hinaus, indem er auf die Vielfalt der jüdischen Elemente in der byzantinischen Hymnographie und Liturgie hinweist. Schwester Éliane Poirot bietet schließlich einen knappen Überblick über den ganzen jüdisch-christlichen Dialog der Moderne aus der Perspektive der Schritte, die die 
from the perspective of the steps tak- römisch-katholische Kirche unternomen by the Roman Catholic Church. men hat. Dabei bietet sie auch wertvolle It also provides valuable information Hinweise auf das Stadium des formellen on the stage of formal and informal und informellen Dialogs in Rumänien. dialogue in Romania.

Wir danken allen, die zu dieser

We thank all those who contrib- Nummer beigetragen haben, vor allem uted to this issue, especially since da einige der Autorinnen und Autoren some of the authors are also speak- auch Referenten der oben genannten ers at the above-mentioned confer- Konferenz sind, die sich dem Bild der ence dedicated to the image of the Juden in der byzantinischen Liturgie Jews in the Byzantine liturgy. We widmet. Wir sind überzeugt, dass die are convinced that the results of Resultate des Forschungsprojektes the research project will provide neue, notwendige Instrumente an die new, necessary tools to balance the Hand geben, um die Diskussion zum discussion on the Judeo-Christian jüdisch-christlichen Dialog aus orthodialogue from a Christian Orthodox doxer Perspektive auf ausgewogene perspective. Thus, the presentations Art und Weise zu führen. So können and contributions of the conference die Vorträge der Konferenz und die in this issue of RES can also help in Beiträge in dieser Ausgabe von RES the consolidation of a more critical auch dazu beitragen, den kritischen perspective on the close relationship Blick auf die enge Beziehung zwischen between Orthodoxy and liturgy. Orthodoxie und Liturgie zu schärfen.

Alexandru Ioniță 